такого обучения должны быть водители-профессионалы осознающие свою ответственность в управлении транспортными средствами.

Использование 3D моделирования в изучении теории ПДД позволяет реализовать принцип индивидуализации обучения, повысить активность обучаемых, интенсифицировать учебную деятельность, повысить эффективность усвоения материала, сформировать культуру поведения будущих водителей на дорогах.

Список литературы:

1. Якимов А.Ю. Совершенствование системы подготовки водителей автотранспортных средств на основе оптимального определения категорий (видов) водителей (с учетом отечественного и зарубежного опыта) [Электрон, ресурс] / А.Ю. Якимов // Безопасность дорожного движения: сборник научных трудов. - МВД РФ (Москва), 2013. - С. 11 - 27. - Режим доступа: http://elibrary.ru/defaultx.asp.

2. Использование мультимедийных технологий в процессе преподавания теории правил дорожного движения. (Преподаватель автошколы АМК - Мануков Ю.И.) http://www.avtomotoclub.ru/information/2071-mylttex.html

3. Хуторской А.В. Ключевые компетенции как компонент личностноориентированного образования // Народное образование. - 2003. - № 2.

\title{
Организация деятельности молодых ученых в современной научно- образовательной среде
}

Мигунов Р.А., ассистент, Российский государственный аграрный университет МСХА имени К.А. Тимирязева, 2. Москва E-mail: migunovrishat@mail.ru

Глобальные тенденции развития человеческого социума убедительно доказывают, что стратегические преимущества будут у тех государств, которые смогут эффективно и продуктивно использовать инновационный потенциал развития. При этом российское Правительство в основах государственной политики заявляет, что именно молодежь способна реализовывать реформы на основе глубокого развития молодежной науки. Молодежь России как наиболее восприимчивая и мобильная часть социума всегда поддерживала прогрессивные реформы и претворяла их в жизнь. Патриотические устремления молодежи развивали науку и промышленность, обеспечившие рост экономики и улучшение качество жизни людей.

Основы государственной молодежной политики Российской Федерации на период до 2025 года определяют тех, кого можно считать именно "молодыми учеными": «работник образовательной или научной организации, имеющий ученую степень кандидата наук в возрасте до 35 лет или ученую степень доктора наук в возрасте до 40 лет либо являюшийся аспирантом, исследователем или преподавателем образовательной организаџии высшего образования без ученой степени в возрасте до 30 лет» [1, с. 2-3].

Стратегия научно-технологического развития Российской Федерации особое внимание уделяет развитию современного научно-технического творчества молодежи и 
адресной поддержки молодых ученых и специалистов в области научной, научнотехнической и инновационной деятельности, результаты деятельности которых обеспечивают социально-экономическое развитие России [2, с. 14]. Создание возможностей для выявления талантливой молодежи, построения успешной карьеры в области науки и технологий и развитие интеллектуального потенциала страны достигаются путем:

- долгосрочного планирования приоритетных научных проектов, позволяющих формировать конкурентоспособные коллективы, объединяющие исследователей, разработчиков и предпринимателей;

- усиления роли репутационных механизмов в признании научной квалификации и заслуг исследователей, повышение авторитета ученых в обществе;

- развития современной системы научно-технического творчества детей и молодежи;

адресной поддержки молодых ученых и специалистов в области научной, научнотехнической и инновационной деятельности;

- создания при ведущих научных и образовательных организациях социальной, прежде всего жилищной, инфраструктуры, необходимой для обеспечения целевой мобильности участников научно-технологического развития.

Задача комплексной модернизации РГАУ-МСХА имени К.А. Тимирязева с перспективой получения официального статуса Национального исследовательского аграрного университета должна опираться, в первую очередь на молодые научные кадры нашей академии. В рамках Стратегии развития университета на период до 2030 г. необходимо создать условия для научного творчества обучающихся и молодых ученых.

2.2.a.1. Создание центров талантливой молодежи по основным научным направлениям университета

2.2.a.2. Создание условий участия молодых ученых, аспирантов и студентов в конкурсах на получение российских и международных грантов (РФФИ, РГНФ, Президента Российской Федерации и др.)

4. Проведение в университете международных англоязычных конференций молодых ученых в сферах опережающего развития и мирового уровня исследований

4.4.a.2. Развитие вузовской системы грантов для молодых преподавателей, научных сотрудников и аспирантов [3, с. 36].

Реализация поставленных целей может и должна осуществляться при помощи общественных организаций академии. Совет молодых ученых РГАУ-МСХА имени К.А. Тимирязева - это общественная молодежная организация, призванная содействовать профессиональному становлению молодых исследователей, защите их профессиональных и социальных интересов, накоплению опыта и творческому росту. В составе совета наиболее активные аспиранты и молодые ученые и специалисты с 8 факультетов и 2 институтов академии. В целях обмена информацией об основных результатах научной деятельности, организационной поддержки коллективов молодых ученых, пропаганды результатов исследований Совет молодых ученых в последние годы провел три международные научные конференции и две конференции регионального уровня. Данные мероприятия позволили привлечь более 800 молодых ученых Тимирязевки. Приглашены были также гости из стран ближнего и дальнего зарубежья (Белоруссия, Казахстан, Украина, Финляндия, Германия, Словакия, Болгария), а также молодые ученые из других регионов Российской Федерации. По результатам 
деятельности Совета опубликованы сборники научных трудов, последние три года размещаемые в Российском индексе научного цитирования и на сайте академии.

Для того чтобы консолидировать молодежь Тимирязевки и оповещать молодых сотрудников о различных мероприятиях, было организовано информационное обеспечение деятельности СМУ: создана веб-страница на сайте университета; организован общий е-mail; ведется сбор информации о грантах для молодежи, проведении летних молодежных школ, молодежных научных конференций и прочее организована регулярная рассылка информации молодым ученым института через систему электронных рассылок и оповещения в социальных сетях. Совет активно участвует в жюри различных конкурсов, среди которых: Начинающий фермер, Агросалон (это выигрышно, надо показать более выпукло) Конкурс на лучший сборник научных трудов аграрных ВУЗов.

Не останавливаясь подробно на организационных вопросах деятельности Совета, хотелось бы осветить вызовы, стоящие перед молодыми учеными и предполагаемые механизмы для разрешения этих противоречий. Среди проблем функционирования СМУ, которые существуют на сегодняшний момент и были в прошлом, можно выделить следующие:

1) Отсутствие значимых преимуществ вступления в СМУ для молодых ученых.

2) Практическое отсутствие ротации кадров внутри СМУ. Заниматься ответственной деятельностью способны не многие. При этом наиболее успешные молодые ученые имеют мало свободного времени, а работа руководства Совета держится на энтузиазме, который не бесконечен.

3) Разобщенность сообщества молодых ученых. С одной стороны, наиболее активная часть научной молодежи занимается исключительно собственной карьерой, с другой неактивные молодые ученые не желают выполнять работу сверх установленных должностных обязанностей.

Пути решения проблем:

1) Регламентирование деятельности СМУ, прав и обязанностей, а также преимуществ членства в СМУ «сверху».

2) Финансирование деятельности Советов на местах.

Для поддержки роста молодых ученых в академии необходимо соблюдение двух условий. Во-первых, должна была выстроена понятная система карьерных траекторий, что должно позволить молодому ученому планировать и гибко корректировать свою карьеру. Движение по выбранной траектории должно быть сопряжено с постоянным прохождением конкурсных процедур, как единственного способа перехода на новый этап. Во-вторых, должна существовать система поддержки перехода на каждый новый этап карьерного роста. Отсутствие поддержки хотя бы на одном уровне приведет к разрыву роста, что разрушит всю систему в целом.

Инвестиции в молодых ученых позволят сформировать принципиально новое понимание места молодежи в науке, предоставление молодым людям не просто гарантий и ресурсов, но и обеспечение реализации их творческого, интеллектуального, физического потенциала в целях развития всей страны.

\section{Список литературы:}

1. Основы государственной молодежной политики Российской Федерации на период до 2025 года (утверждены распоряжением Правительства Российской Федерации от 29 ноября 2014 года №2403-р). [Электронный ресурс]. Режим доступа: 
http://government.ru/media/files/ceFXleNUqOU.pdf, свободный (дата обращения: 06.02.2017). - $14 \mathrm{c}$.

2. Стратегия научно-технологического развития Российской Федерации (утверждена Указом Президента РФ от 1 декабря 2016 года №642). [Электронный pecypc]. Режим доступа: http://docs.cntd.ru/document/420384257, свободный (дата обращения: 06.02.2017). - 24 с.

3. Стратегия развития федерального государственного бюджетного образовательного учреждения высшего образования «Российский государственный аграрный университет - МСХА имени К.А. Тимирязева» на 2016-2030 гг. (утверждена ректором РГАУ-МСХА имени К.А. Тимирязева от 30 июня 2016 г.). [Электронный pecypc]. Режим доступа: http://www.timacad.ru/about/data/docs/strategiya-2016-2030.pdf, свободный (дата обращения 06.02.2017 г.). - 124 с.

\title{
Выявление и формирование уровня готовности студентов к выполнению нормативов комплекса «Готов к труду и обороне» (на примере групп общефизической подготовки ТИ (ф) СВФУ)
}

\author{
Мороз А.А., студентка, \\ E-mail: anna moroz1995@mail.ru \\ Добрынина А.И., студентка, \\ E-mail: alena.sweet91@mail.ru \\ Технический институт (филиал) \\ Северо-Восточного федерального университета, г. Нерюнгри
}

Научный руководитель: к.n.н., доцент Прокопенко Л.А.

Указ Президента Российской Федерации «О Всероссийском физкультурноспортивном комплексе «Готов к труду и обороне» (ГТО) № 172 от 24.03.2014 г. положил начало возрождению российских традиций здоровьесбережения нации. Возрождение и внедрение Всероссийского физкультурно-спортивного комплекса ГТО является общенациональной задачей создания эффективной системы физического воспитания, направленной на развитие человеческого потенциала и укрепление здоровья населения.

Исследование физической активности студентов ТИ (ф) СВФУ в свободное время в октябре 2015 г. показало, что большинство опрошенных студентов не занимаются физкультурой и спортом во внеучебное время, особенно во время сессии и каникул, а также в утренние часы [1]. Такой результат настораживает, тем более в период внедрения комплекса ГТО, предусматривающего высокие требования к уровню развития физических качеств.

Для целенаправленной физической подготовки к выполнению нормативов комплекса ГТО одних только учебно-тренировочных занятий недостаточно, поэтому нами был разработан проект, предусматривающий создание положительной мотивации и повышение уровня готовности студентов к выполнению нормативов комплекса ГТО с упором на самостоятельные занятия.

Цель работы - экспериментально проверить эффективность проекта по выявлению и формированию готовности студентов к выполнению нормативов 